https://helda.helsinki.fi

\title{
Agamben, Badiou and Affirmative Biopolitics
}

\section{Prozorov, Sergei}

Edinburgh University Press

2016-07-20

Prozorov , S 2016 , Agamben, Badiou and Affirmative Biopolitics . in D McLoughlin (ed.), Agamben and Radical Politics . Critical Connections, Edinburgh University Press , Edinburgh , pp. 165-188 . <

https://edinburghuniversitypress.com/book-agamben-and-radical-politics.html >

http://hdl.handle.net/10138/303964

acceptedVersion

Downloaded from Helda, University of Helsinki institutional repository.

This is an electronic reprint of the original article.

This reprint may differ from the original in pagination and typographic detail.

Please cite the original version. 
This is an Accepted Manuscript of a book chapter published by Edinburgh University Press in Agamben and Radical Politics on July 20th, 2016, available online: https://edinburghuniversitypress.com/book-agamben-and-radical-politics.html.

Sergei Prozorov

\section{Agamben, Badiou and Affirmative Biopolitics}

\section{Introduction}

Agamben and Badiou are rarely discussed together, especially in the context of politics. Even though both authors reached the height of their international fame at the same time and represented the next wave in continental philosophy after the predominance of 'poststructuralism', the difference of their interests, influences and, not the least, styles often makes it difficult to see what common tendency these authors exhibit. While a number of studies have addressed affinities between Agamben and Badiou in terms of their interest in formalism and the problems of reference (Livingston 2012; Clemens 2008), the discussions of the two authors have generally tended to accentuate the differences between them, even when they are addressing the same theme, e.g. Pauline messianism (see Kaufman 2008; Baker 2013).

This is easy to understand, since the differences in question appear so evident as to form pedagogically helpful oppositions, between e.g. Badiou's rehabilitation of grand systematic philosophy and Agamben's reinvention of the fragmentary genre, Badiou's daring abandonment of the linguistic and discursive focus of French philosophy and Agamben's insistence on the ontological significance of language, Badiou's reaffirmation of radical emancipatory politics and militant activism and Agamben's wariness of communism and revolutionary politics as complicit in the biopolitical tendency of the West. In this chapter we will challenge at least the latter opposition, not because it is incorrect as such but because it occludes an important proximity between the two authors in the ontopolitical dimension. The elucidation of this proximity will also help render the contribution of both authors to radical politics more intelligible, offering a more nuanced interpretation of Badiou's alleged overcoming of nihilistic biopolitics in favour of militant communism and a more explicitly political reading of Agamben's often arcane meditations on the form-of-life. 
We shall begin by addressing the two areas of explicit disagreement between Agamben and Badiou in order to demonstrate that the two authors' positions are in fact much closer than they themselves cared to admit. Firstly, we shall address Agamben's criticism of Badiou's interpretation of Paul as a universalist and his alternative interpretation of Pauline messianism in terms of the logic of the remnant. We shall argue that Agamben's critique would only be valid if Badiou affirmed a traditional hegemonic notion of universalism, which he definitely does not. In contrast, his account of universality in generic and indiscernible terms accords with Agamben's interpretation of Paul in a number of important ways. We shall also show that while Agamben is reluctant to deploy the concept of universalism (as well as many other central concepts of the Western political tradition), he has shown a persistent interest in rethinking universality in generic terms from his early writings onwards. Agamben's criticism of Badiou in The Time that Remains thus fails to recognize his proximity to his own position.

Secondly, we shall address the reverse case of Badiou misrecognizing the proximity of Agamben's stance to his own. In his extended note in Logics of Worlds Badiou accused Agamben of the valorization of weakness and passivity in his account of bare life, which contrasts sharply with his own affirmation of militant activism of the subject of the truth procedure. The figure of Bartleby, which Agamben discusses appreciatively and Badiou curtly dismisses, offers a good illustration of what is at stake in this discussion. We shall show that despite Badiou's interest in historical sequences of 'grand politics' as examples of his politics of truth, his own militant practice is much closer to the Bartleby-politics of inoperativity associated with Agamben. The presentation of the two authors' stances as a simple opposition of activity/passivity, strength/weakness, militancy/victimhood is therefore too simplistic and does justice to neither of them.

These two instances are important not merely as the most explicit points of disagreement between Agamben and Badiou. They also serve as a starting point for our more general and provocative argument about a more fundamental affinity between the two authors in the context of biopolitics. While Agamben considers the biopolitical problematic the sole remaining site for thinking politics and Badiou rejects the biopolitical lexicon as part of nihilistic 'democratic materialism', we shall argue that both authors are working through the possibility of an affirmative biopolitics that would not negate life in the name of its protection or transformation. By retracing the account of the generation of truths in Badiou's meta-ontology we shall 
demonstrate a striking similarity of his concept of the body of truth to Agamben's notion of the form-of-life.

Of course, this similarity does not efface the differences between the two authors that remain important. The task of this chapter is not to argue that the political philosophies of Agamben and Badiou are alike, let alone identical. Our argument is rather that the reconstitution of an ontopolitical orientation common to both authors permits to relocate these differences into the more appropriate context of methodology, style or even temperament. It is certainly true that Agamben prefers Bartleby to Spartacus, while Badiou finds more to admire in the Great Proletarian Cultural Revolution than in the Tiananmen Square protests. Yet, these preferences do not efface the same ontopolitical tonality in the work of the two authors, which is at the same time extremely affirmative and highly minimalist, affirming in forms of life nothing but their facticity, their sheer being-thus, which becomes the condition of possibility of radical political transformation.

\section{Whatever Being and the Problem of Universalism}

The first area of disagreement between Agamben and Badiou pertains to the interpretation of St Paul and the question of universalism. Badiou's 1997 book St Paul: The Foundation of Universalism marked the beginning of what might be called a new 'universalist turn' in continental philosophy after decades of discredit in poststructuralist philosophies of difference. In his book Badiou offered a stinging critique of particularistic 'identity politics', which he viewed as a necessary complement of the pseudo-universality of capitalism. He ventured to overcome this rampant particularism with a universalist politics of truth, the paradigm of which he found in Pauline epistles. Badiou reinterprets Pauline texts from his own ontological perspective, finding in Paul the examples of his categories of the event, intervention, fidelity and truth. Brusquely bracketing off the narrowly religious content of Paul's epistles as a 'fable' (Badiou 2001b: 4), Badiou reconstructs the formal model of Pauline universalism, arising from the event of Christ's resurrection, which is important solely as a starting point for the procedure that it launches:

Paul's general procedure is the following: if there has been an event, and if truth consists in declaring it and then in being faithful to this declaration, two consequences ensue. First, since truth is evental, it is singular. It is neither structural, nor axiomatic, nor legal. No available generality can account for it, nor structure the subject who claims to follow 
in its wake. Consequently, there cannot be a law of truth. Second, truth being inscribed on the basis of a declaration that is in essence subjective, no preconstituted subset can support it; nothing communitarian or historically established can lead its substance to the process of truth. Truth is diagonal relative to every subset; it neither claims authority from, nor constitutes any identity. It is offered to all, or addressed to everyone, without a condition of belonging being able to limit their offer or this address. (Badiou 2001b: 14)

Thus, the truth that Paul affirms is a singular universality, an effect of the rupture of the event in a given world that carries universally valid consequences that cannot be restricted by any conditions of belonging. The Christian subject is constituted by one's intervention into the situation that declares the occurrence of the event and one's subsequent fidelity to it. The subject of truth does not, in Paul's famous words, discern between Jews and Greeks, men and women, free persons and slaves, and is generally indifferent to the particular words or situations, in which the process of truth unfolds, remaining 'subtracted from the organization of subsets prescribed by the State' (ibid.: 15).

In his Time that Remains, published in Italian three years after the publication of Badiou's book, Agamben explicitly rejects Badiou's designation of Pauline messianism as universalist. In Agamben's reading, rather than offer a truth 'for all' (the conventional understanding of universalism), Paul affirms the non-coincidence of 'all' with themselves, whereby the particularistic division into Jews and Greeks, men and women, etc., is divided once more according to a new criterion, the distinction between 'flesh' (apparent, superficial belonging valid only in the eyes of the law) and 'breath' (genuine belonging on the basis of fidelity). We thus end up with a figure of the 'remnant' that does not fit in the opposition of Jews and non-Jews - a 'non-non-Jew' who is not under the positive law of a particular community but rather under the law of the Messiah. 'At this point one can measure the distance that separates the Pauline operation from modern universalism - when something like the humanity of man is taken as the principle that abolishes all difference or as the ultimate difference beyond which further division is impossible.' (Agamben 2005: 52)

While Badiou's reading of Paul emphasizes his indifference to differences, whereby particularities become tolerated as the sites traversed by universality, which must always be affirmed locally within a situation (Badiou 2001b: 98-99), Agamben goes beyond what appears to him to be a mere benevolent or condescending 'tolerance'. What the Pauline double division does is render 
the operations of the law and other apparatuses that establish and sustain difference inoperative so that '[all] that is left is a remnant and the impossibility of the Jew or the Greek to coincide with himself, without ever providing [one] with some other identity. You see why it makes no sense to speak of universalism with regard to Paul, at least when the universal is thought of as a principle above cuts and divisions and the individual as the ultimate limit of each division.' (Agamben 2005: 53)

The problem, nonetheless, is that the universal is not thought that way by Badiou. As a singularity that is not anticipated, prescribed by or subsumed under any law, it is clearly not 'above' cuts and divisions, but rather itself consists in the subtractive cut that separates one from the identities prescribed by the positive order that Badiou terms 'the state of the situation'. Secondly, as a subjective process that does not pre-exist the declaration of the event, universality cannot be localized within any particular subset, be it a group or an individual. Badiou's 'for all' is not identical to what Agamben terms 'modern universalism', which posits a difference (e.g. humanity) that abolishes all differences, but rather consists in the subtraction from all differences that resembles the messianic division that produces the figure of the remnant. Badiou's political subject, subtracted from its 'intra-worldly' determinations, is best grasped precisely as a 'nonnon-Jew' (Greek, man, woman, etc.), the second negation negating the first and making it irrelevant.

In fact, in his earlier writings on language and community Agamben himself affirmed a conception of universality that resonates strongly with Badiou's subtractive universalism. These works are particularly influenced by Walter Benjamin's essay 'On Language as Such and on the Language of Man' (Benjamin 1978: 314-332), where Benjamin addressed the idea of a pure language irreducible to any actually existing particular languages. While the latter remain subjected to the communicative function and hence reducible to mere signs, pure language would be strictly self-referential, no longer mediated by meaning, a language 'that does not mean anything but simply speaks' (Agamben 1999: 54). It would therefore signify nothing but its own existence and refer only to its own communicability, which Benjamin terms 'the expressionless word' (cited in Agamben 1999: 53). For both Benjamin and Agamben, all languages express this communicability, yet in every particular language it remains crowded out by particular signified content: 
All historical languages, Benjamin writes, mean pure language. It is what is meant in every language, what every language means to say. On the other hand, however, it itself does not mean anything; it does not want to say anything, and all meaning and all intention come to a halt in it. We may thus say that all languages mean to say the word that does not mean anything. (Agamben 1999: 53)

Agamben's later reinterpretation of political community is based on the transfer of this logic of universal language to the political realm. Bracketing off both particular languages and particular communities, he instead focuses on two elementary 'facts', factum loquendi and factum pluralitatis, the fact of language as pure communicability and the fact of multiplicity or plurality, that the respective sciences of language and politics both presuppose and efface (Agamben 2000: 66). For Agamben all particular human communities (nations, states, cultures) seek to express the sheer factum pluralitatis of human multiplicity, which nonetheless remains ineffable in them, concealed by particular positive contents of these communities that serve as conditions of belonging to them and exclusion from them. Yet, the universal community that the factum pluralitatis affirms does not itself express anything, has no determining predicate or positive content, but simply exposes the being-in-common of all beings. Just as the universal language extinguishes all linguistic meaning but simply speaks, the universal community subtracts itself from every determinate aspect of belonging and simply exists as neither this nor that (Jew or Greek, male or female), but solely as 'thus' or 'whatever' (1993: 1-3, 17-21).

This understanding of the universality of language and community is clearly distinct from a simple reaffirmation of familiar liberal (Rawlsian or Habermasian) or Marxist universalisms, which explains Agamben's consistent refusal of the very label of universalism (see 1993: 9). While, as we have seen, Badiou's version of universalism is just as far from the traditional notion of universalism, his terminological strategy is strictly the opposite of Agamben's and consists in enthusiastically adopting the term while radically transforming its content. In fact, these different choices characterize the two authors' approaches more generally. Throughout his work Agamben has been wary of any positive identification with many of the key terms of the Western ontopolitical tradition, which for him are hopelessly compromised by its biopolitical inflection: 'terms such as sovereignty, right, nation, people, democracy and general will by now refer to a reality that no longer has anything to do with what these concepts used to designate - and those who continue to use these concepts uncritically literally do not know what they are talking about.' (Agamben 2000: 110) In contrast, Badiou has proceeded by reappropriating and 
transforming such key terms of the Western tradition as the subject, truth and equality (see Badiou 2008: 147-176). Important as it is, this difference should not obscure the fact that the two authors' interpretations of Pauline messianism remain structurally similar, highlighting the subtractive character of messianic politics. This is in fact also the view of Badiou himself, who, as we shall see below, is otherwise quite explicit about his disagreements with Agamben:

[1] know that Agamben's reading of Paul is very different from mine, but is this difference really a contradiction? In Paul there is an interplay between separation and universalism. For Paul, there is certainly a kind of separation necessary for his universalism because we have separated ourselves from the old man. We have, out of this separation, a newness of life. But it remains a universalism because there is no limit to this separation, there is no closure. Instead, [Paul] proposes something that is open to everybody, a collective determination, the realization of a separation in a universal field. So, naturally, there is, for Paul, in the process of universalism, something like division but this is a division internal to the subject itself. So I perfectly understand that unive rsalism can take the form of a separation. There is always something like an intimate division when universalism takes the form of a separation. But there is never the pure opposition of universalism and separation because there is something like the becoming-separate of a universalism. (Badiou 2005b: 39-40)

For Agamben, the separation within the subject leaves the remnant of 'whatever being' or 'being thus' that cannot constitute any overarching or hegemonic identity but only refers to the sheer factum pluralitatis of being-in-common, to beings taken up solely in their being. Yet, Badiou's universalism is constituted by the very same movement of separation or subtraction. Badiou's technical term for Agamben's 'remnant' is the 'generic' subset of the situation, which Badiou identifies with its truth. The generic subset that comprises the elements of the situation connected with the event is indiscernible within this situation, i.e. cannot be individualized by any of its positive predicates; it 'contains a little bit of everything [but] only possesses the properties necessary to its existence as multiple in its material. It does not possess any particular, discerning, separative property. At base, its sole property is that of consisting as pure multiple, of being. Subtracted from language, it makes do with its being.' (Badiou 2005a: 371)

It is this indiscernible, non-identitarian mode of being that both Agamben and Badiou find in Paul and make the basis of their political philosophies. For both authors whatever being, 
subtracted from every positive determination, serves as the basis for subverting and transforming the particular orders of 'worlds' (Badiou) or 'apparatuses' (Agamben) that themselves have no ontological foundation (Badiou 2009: 75, 357-380; Agamben 2011: 53-66). While the two differ on whether this mode of being should be termed universal, it is clear that both of them critically target the more familiar hegemonic or imperialist forms of universalism. Just as universal language was not intended as a forcible reorganization of the myriad ways, in which people communicate, that would makes them speak a new language, so the universal political community is never attained by unification or integration of particular communities but rather by subtraction, separation and division that traverse every subject, be it an individual or a group. This approach does not merely not contradict pluralism but rather proceeds through a thoroughgoing pluralization that leaves nothing identical with itself.

\section{Bartleby and the Problem of Bare Life}

The second instance of disagreement between Agamben and Badiou that we shall address pertains to the attributes of the politics based on this generic mode of being. Whereas Badiou has famously sought to rehabilitate the politics of militant activism in the affirmation of political truths, Agamben's writings have been characterized by a focus on situations of extreme disempowerment, deprivation and dehumanization, in which political activism appears impossible. Particularly emblematic in this respect is Agamben's reading of Melville's Bartleby, which was interpreted by critics as an indication of his excessive pessimism, which only finds an elusive spark of redemption in utter abjection and suffering, with which it is preoccupied to such an extent that some observers termed his approach 'pornographic' (Bernstein 2004; cf. Prozorov 2011). According to these accounts, if there is such a thing as 'Bartleby-politics' (cf. Zizek 2006: $342-3,381$ ), it must be a politics that is from the outset resigned to failure (Whyte 2009; Chiesa 2009).

In an extended note in his Logics of Worlds Badiou has similarly contrasted his own affirmative project with Agamben's valorization of weakness.

[Agamben's] recurrent theme is being as weakness, its presentational poverty, power preserved from the glory of its act. Likewise, in politics, the hero is the one brought back to its pure being as a transitory living being, the one who may be killed without judgment, the homo sacer of the Romans, the Muselmann of the extermination camp. 
Agamben, this Franciscan of ontology, prefers, to the affirmative becoming of truths, the delicate, almost secret persistence of life, what remains to one who no longer has anything; this forever sacrificed 'bare life', both humble and essential, which conveys everything of which we - crushed by the crass commotion of powers - are capable of in terms of sense. (Badiou 2009: 558-559)

At first glance, the difference between the two authors is clear. Badiou's political subject actively struggles to pursue the truth of the event in the world, putting its life at risk, and is often defeated, only be 'resurrected' in a new vehicle of the truth. In contrast, Agamben's political subject is always already defeated, if not outright destroyed, by the power it confronts, and the sole truth it 'delicately' or 'secretly' affirms is that of its own bare life devoid of any property. Badiou's difference from Agamben is well illustrated by his hasty dismissal of Bartleby, whose famous 'I prefer not to' is perhaps the best example of Agamben's notion of inoperativity. In Logics of Worlds Badiou picks Bartleby as an example of the negation of a truth by its subject in the form of betrayal: 'One can, like the office clerk Bartleby in Melville's eponymous novella, 'prefer not to'. But then a truth will be sacrificed by its very subject. Betrayal.' (Badiou 2009: 400) This reading is quite staggering, since Bartleby never betrayed anything or anyone, let alone the truth. On the contrary, his 'preference not to' arguably was his truth that he actually upheld faithfully until his death. Moreover, in its very lack of positive content this truth is not so far from Badiou's own presentation of truth as indiscernible, generic and universal (2005a: 327-354). Bartleby is a personification of a singular life subtracted from all particular predicates and is therefore closest to the model of universalism described above (see Deleuze 1997: 74).

Of course, Badiou's own favourite examples of political subjects are a world away from Bartleby: Spartacus, the French Communards, Mao, etc. (2009: 24-27, 51-57, 64-65, 493-503). Throughout his works Badiou offers grand examples from the history of emancipatory and revolutionary politics (slave uprisings, peasant revolts, proletarian revolutions), which are all based on the transhistorical invariant that he terms 'the communist hypothesis' of radical equality (Badiou 2010). In contrast, Agamben's political subjects tend to be rather less than heroic, even as they might also traverse some of these grand-political sequences as survivors or witnesses: Bartleby, Kafka's Joseph K and K the land surveyor (Agamben 2010: 20-35), Tiananmen protesters (1993: 85-86), Anna Akhmatova (1999: 177-178), etc. Yet, we cannot help but notice that for all the heroism of their protagonists all of Badiou's grand-political sequences have ended in failure, be it in the form of defeat, retreat, betrayal or the perversion of original goals. Of course, these 
failures were often highly instructive, e.g. demonstrating the direction that would be fatal for the truth procedure and thus serving to sustain it within history (cf. Badiou 2010: 1-40). Yet, while Badiou succeeds in incorporating failure within the positivity of the truth procedure, this very incorporation ensures that the 'affirmative becoming of truths' is not without its own immanent negativity.

Moreover, some of the episodes in the unfolding of Badiou's politics of truth, e.g. $20^{\text {th }}$ century revolutionary movements, have brought to the forefront of politics the very bare life that Badiou wishes to dismiss as politically irrelevant: Any serious engagement with $20^{\text {th }}$ century socialism cannot ignore the facts of terror, famine and the Gulag (see Prozorov 2013 for a detailed discussion). This link between grand revolutionary politics and the inclusive exclusion of bare life supports Agamben's argument in Homo Sacer about the belonging of the revolutionary tradition of constituent power to the overall biopolitical constellation of Western politics (1998: 46-47). Agamben has opposed the attempts of radical-democratic and communist thought to overcome the logic of sovereignty by the valorization of constituent power as potentiality inexhaustible in any actual form of constituted structure of authority. Instead, he demonstrates that the opposition between constituent and constituted power is only apparent, since both dimensions are at work in the logic of sovereignty that includes its own suspension in its operations. Sovereignty is not (merely) the force of actualization that exhausts all potentiality but also the force of potentiality that manifests itself in actuality in the form of the state of exception, whose paradigmatic nomos is the camp. The appearance of bare life as the product of $20^{\text {th }}$ century revolutionary regimes is by no means coincidental or attributable to some deviation or perversion of the revolutionary intention. As long as revolution is conceived in terms of constituent power, bare life, the camps and other unsavoury aspects of sovereignty can never be left behind.

There is, however, an important exception to Badiou's commitment to grand politics, which is none other than Badiou himself as a political subject. Badiou's own micro-political engagement in the now-defunct Organisation Politique (OP) (Badiou 2001 a: 95-119; Hallward 2003: 43-45, 227 242) was characterized by action at a distance from the state, the refusal to take part in elections and the renunciation of all figures of political representation. Badiou's Organisation was completely uninterested in instituting a new political system but was solely concerned with undermining the existing order on the basis of the axiomatic affirmation of equality. This approach is quite different from those of Spartacus, Mao and other heroic leaders of popular 
rebellions and revolutions that Badiou discusses in his works on politics. Indeed, in its combination of utter radicalism and practical modesty, axiomatic tone and strategic ineffectiveness, Badiou's own politics is, dare we say, somewhat Agambenian. While as a philosopher of politics Badiou prefers grand examples of revolutionary politics, in his own activity as a political subject he is a lot like Bartleby, repeatedly 'preferring not to' run in elections, read mainstream press, act in accordance with any managerial rationality or the imperative of profit, etc. (Badiou 2008: 43-50).

Once again, the disagreement between the two authors is rather less pronounced than it first appeared. Yet, does not Badiou's critique actually point to the ultimately irreducible difference between him and Agamben, the one pertaining to the political status of bare life or life as such? While Agamben has painstakingly pursued the possibility of an affirmative biopolitics, in which the living being would be the subject and not the object of power, Badiou has derisively dismissed the biopolitical problematic as one more illustration of the contemporary nihilism and has instead affirmed the politics of truth irreducible to the vital interests of the human animal. Even if it is granted that Badiou's generic universality is close to Agamben's non-identitarian remnant or that Bartlebyan inoperativity is not that far from Badiou's own version of militancy, the fact remains that Agamben finds the true locus of politics in the same terrain that for Badiou a genuine politics necessarily transcends. In the final section we shall contest such an interpretation, arguing that it is precisely on the terrain of biopolitics that the affinity of Agamben and Badiou becomes fully intelligible.

\section{Form-of-Life and the Body of Truth}

Badiou has long been a principled opponent of biopolitics (Johnston 2013: 89-91; Livingston 2012: 240; Lewis 2007: 55-58). His writings since the 1980s have featured passionate polemics against the reduction of politics to the management of the bare existence of human beings. For Badiou biopolitics, which he discusses in his Logics of Worlds under the rubric of 'democratic materialism', has become a spontaneous ideology of late-modern Western societies: '[There] are only bodies and languages. Human rights are the same as the rights of the living. The humanist protection of all living bodies: this is the norm of contemporary materialism. Today, this norm has a scientific name: 'bioethics', whose progressive reverse borrows its name from Foucault: 'biopolitics'. Our materialism is therefore a materialism of life. It is a bio-materialism.' (2009: 2) This characterization of contemporary politics goes back to Badiou's Ethics, whose key target was 
the reduction of the human being to the 'living animal', a 'biped without feathers whose charms are not obvious' (2001a: 12). Similarly, in The Century (2007: 175-177) Badiou scorned the 'animal humanism', promoted by contemporary liberal democracies, in which man figures only as a potential object of suffering, oppression, torture or genocide - in short, a 'pitiable animal'.

To these ethico-political discourses Badiou opposes a militant politics of truth, which consists in the affirmation of radical equality of all beings, hence his identification of this politics with the 'communist hypothesis'. Notwithstanding this opposition, the two key terms of biopolitics, the body and life, reappear in Badiou's politics of truth. Firstly, a politics concerned with the needs and desires of individual bodies is overcome through the constitution of a new, subjectivized body of truth, into which individual bodies are incorporated and become vehicles of universal, infinite and immortal truth (2009: 33-34). Secondly, while Badiou is scornful about the use of life in its biological sense as the sole object of politics, his politics is oriented towards attaining a 'true life', defined as the participation in the subjective body of truth (ibid.: 507).

In fact, Badiou's attempt to overcome biopolitics by overcoming biological life in favour of some other form of life follows almost to the letter the logic of biopolitics as presented by Agamben, i.e. the 'inclusive exclusion' of zoe from bios. Agamben starts from the distinction between two terms for 'life' in Ancient Greek: 'zoe, which expressed the simple fact of living common to all living beings (animals, men or gods) and bios, which indicated the form or way of living proper to an individual or a group.' (Agamben 1998: 1) While zoe is sometimes interpreted as natural or even biological life, what Agamben emphasizes is not any specific 'natural' qualification, but, on the contrary, the absence of any qualifications, which makes zoe common for humans, animals and gods. In the argument of Homo Sacer, the constitution of bios as the political form of life presupposes the entry of zoe into this realm in the marginalized, subordinated or suppressed position: it is included in the polis, but solely in the mode of its exclusion from it, as a negative foundation, 'as if politics were the place in which life had to transform itself into good life and in which what had to be politicized were always already bare life' (Agamben 1998: 7). It is this negative foundation that Agamben terms 'bare life'. While zoe is originally unqualified, bare life is qualified negatively by the fact of its exclusion, reduced to the 
sheer facticity of living. There is therefore nothing natural about it; on the contrary, as Agamben's examples of homo sacer and the Muselmann suggest, this life stripped of all protections and exposed to violence might well be the most unnatural thing of all. Perhaps, a 'bared' or 'stripped' life would be a better term, highlighting the violence involved in the process of the constitution of a political form of life on the basis of the negative foundation of the simple fact of living.

It is easy to observe the parallels between this logic and Badiou's 'body of truth'. As Agamben himself argued, '[Badiou] still conceives of the subject on the basis of a contingent encounter with truth, leaving aside the living being as the 'animal of the human species' as a mere support for this encounter.' (Agamben 1999: 221) The true life of the 'superhuman' subject is obtained by the isolation of the physical life of the subhuman 'mortal animal' as its material support (Badiou 2001a: 12-13).If that was all there was to Badiou's politics of truth, then it would amount to little more than a replication of the disavowal of the 'merely human' in modern biopolitics (Badiou 2007: 178. See e.g. Wolfe 2013: 28-30). The question of biopolitics would then indeed divide Agamben and Badiou, insofar as the latter would remain stuck in the same biopolitical paradigm, whose liberal version he so vehemently criticizes. Yet, such a conclusion would be rather uncharitable since it would ignore the content of Badiou's truths. While no variation in content could admittedly change the formal belonging of his politics of truth to the biopolitical logic, it might produce a different kind of biopolitics, i.e. an affirmative biopolitics long debated on in Italian political thought (see e.g. Esposito 2008).

At the end of Homo Sacer Agamben defined such a biopolitics in the following manner: 'This biopolitical body that is bare life must itself instead be transformed into the site for the constitution and installation of a form of life that is wholly exhausted in bare life and a bios that is only its own zoe.'(Agamben 1998: 188) If biopolitics includes zoe into bios in the destitute mode of bare life, whose negation founds the political form of life, then the only possibility for biopolitics to refrain from this negation and begin to affirm life requires that bios and zoe become entirely indistinct. In this manner, life and its form would become inseparable, bios being only its own zoe, so that it is 'no longer possible to isolate anything like a bare life' (Agamben 2000: 9). The sheer facticity of zoe, 'the simple fact of living', will then no longer be negated as a foundation of bios but will rather define its entire content, there being no other form, essence, 
task or identity imposed on it. What Agamben calls form-of-life, the hyphens emphasizing the integrity of life and its form, may then be understood as 'a being that is its own bare existence, [a] life that, being its own form, remains inseparable from it' (Agamben 1998: 188).

Agamben's concept of form-of-life is certainly easy to misunderstand. After all, doesn't a 'bios that is only its own zoe' correspond precisely to the structure of the sovereign state of exception, in which bare life is exposed to death? What is then the difference of form-of-life from bare life as the negative foundation of the political order? While sovereignty operates by capturing and separating bare life from the positive forms of bios or, in what amounts to the same thing, crushing these forms down to the level of pure survival, Agamben makes the opposite move of articulating zoe and bios into a new figure, in which fact and form, the unqualified and its qualification, are no longer separable and neither can dominate the other. In contrast to bare life inclusively excluded in the sovereign state of exception, this life is not $d e$-formed but rather appropriates its simple facticity as the sole form proper to it. It is as if bare life, negated as the foundation of bios, reclaims itself for itself by taking up the space of bios entirely, voiding it of all determinate content. This life, while still in some sense 'bare', is no longer stripped of every possible qualification but rather demonstrates the irreducibility of its being to any such qualification.

[The] only thing that the beautiful face can say, exhibiting its nudity with a smile, is 'You wanted to see my secret? Then look right at it if you can. Look at this absolute, unforgivable absence of secrets!' The matheme of nudity is, in this sense, simply this: baecce! There is nothing other than this. This simple dwelling of appearance in the absence of secrets is its special trembling - it is the nudity that signifies nothing and, precisely for this reason, manages to penetrate us. (Agamben 2010: 91)

We encounter this figure of an integral form-of-life in the most diverse contexts of Agamben's work: the 'coming community' of whatever singularities devoid of identities and vocations (1993), the experimentum linguae that communicates the sheer existence of language and not its signified contents (2007a: 5-6), the 'glorious body' that is nothing but the earthly body divested of its functions and open to a new use (2010: 91-103), the objects of profanation and play that are removed from the 'sacred spheres' regulating their existence and rendered available to free 
experimentation (2007b: 73-91) and, most recently, the attempts of Franciscan monasticism to arrive at a form of life that would not simply apply any existing rules or laws to life or establish alternatives to them, but rather be 'completely extraneous to both civil and canon law', having its entire content in the life of Christ alone (Agamben 2013: 122). What unites all of these diverse figures is their subtraction from every particular predicate and their exposure in the bare facticity of their existence or 'being-thus', the mode of being that we have identified as the source of Badiou's and Agamben's convergent conceptions of the universal. It is important to recall that while this mode of being retains the particular predicates of whatever beings, their very retention makes it impossible for them to function as determinative predicates: being-thus is 'neither this nor that, neither thus nor thus, but thus, as it is, with all its predicates (all its predicates is not a predicate).' (Agamben 1993a: 93). Form-of-life does not deform let alone destroy the particular forms of life, but suspends the determinative function of these forms and instead exposes them solely in the aspect of their being. In other words, whatever beings undergo neither a deprivation (of the old identity) nor a transformation (into a new one), but solely the exposure of the sheer fact that they are in the absence of any identification of what they are. Form-of-life is not some particular bios, but whatever bios grasped solely in the facticity and thusness of its zoe, akin to the language that speaks its own communicability or the community that lives its own existence. In other words, form-of-life is not constituted by any predication of what it is but solely by the exposure of the fact that it is. Would it then be possible that notwithstanding his explicit polemics against bare, biological or animal existence as the object of politics, Badiou's biopolitics has a similarly affirmative orientation?

At first glance, Badiou's polemic against Agamben's valorization of bare life precludes this possibility. Badiou's reading of Agamben presents bare life as what remains of the living being after all positive forms of life were stripped away from it, a remainder that is without any truth of its own. Yet, as we have seen, Agamben's notion of the form-of-life actually performs the reverse gesture of elevating this unqualified remainder to the status of a positive form by erasing any difference between bios and zoe. While Badiou's account of his politics of truth polemically opposes zoe and bios, a more attentive reading of the process of the generation of truths in Badiou's meta-ontology demonstrates that his notion of the body of truth is strictly correlative to Agamben's form-of-life. Let us briefly revisit Badiou's account of this process in Being and Event.

The event which initiates the truth procedure is composed of the elements of the evental site and itself. The evental site is a set that is absolutely singular, i.e., it belongs to the situation but is not 
included into it. The operation of inclusion proceeds by recomposing the elements of the original set into subsets. Since an absolutely singular set is present in the situation as undecomposable, 'all of a piece', it obviously cannot be counted in terms of its parts and thus remains without representation in the metastructure that Badiou terms the 'state of the situation': 'Such a multiple is solely presented as the multiple-that-it-is. None of its terms are counted-for-one as such; only the multiple of these terms forms a one.' (Badiou 2005a: 175.)

The other component of the event is, paradoxically and from a strictly ontological perspective impossibly, the event itself (ibid.: 190) Since the ontological axioms of set theory prohibit selfbelonging, the belonging of the event to the situation can never be objectively inferred from the situation but must rather be decided upon or 'wagered' in the procedure of intervention. This procedure 'names' the unpresented elements that belong to the evental site, affirming the existence of a set without being able to designate it as $a$ being and determine how it differs from other sets. The second procedure called fidelity then groups together the elements of the situation, whose existence is dependent on the event in question, resulting in the formation of that indiscernible subset that Badiou terms the truth and whose universality we have discussed above. Thus, the 'presentational poverty' that Badiou finds in Agamben actually characterizes the entire process of the emergence of the truth, from its origin in the unpresented elements of the situation to its own status as indiscernible in it.

In fact, it is the presentational poverty of the event and the ensuing truth procedure that differentiate Badiou's event from the structure of the state of exception as described by Agamben, despite Agamben's somewhat awkward attempt to demonstrate otherwise (Agamben 1998: 24-25; cf. Clemens 2008: 56-57). While the event is by definition an exception in relation to the situation, its ontological undecidability and the indiscernibility of the truth unfolding from it ensure that it can never be incorporated into the state of the situation as its own, immanent exception that defines Agamben's sovereign ban. 'Ontology has nothing to say about the event,' hence the situation cannot even register it, let alone make use of it in the manner the sovereign makes use of the anomie that it appropriates (Badiou 2005a: 190). Insofar as the event and its consequences are not appropriable by the existing order of the situation, its exceptionality is, in the Benjaminian terms deployed by Agamben, 'real' rather than 'sovereign', i.e. severed from all relation to the law and state and incapable of functioning as their negative foundation (Benjamin 1969: 257). 
If the truth makes do with its being without being discernible in language, if it does not possess any particular properties, its content must be exhausted in what pertains to the situation's very being prior to its internal structuration. This is what makes the truth universal, '[the] truth of the entire situation, of the being of the situation' (ibid.: 525). If the truth had some positive content of its own, it could never have universal consequences for the situation but would merely produce an extraneous addition to it. Yet, as we have seen, the event does not produce any new content, but rather presents what was always in the situation to begin with but was not presented therein. What the truth manifests is nothing more (and nothing less) than the being of the situation or world as inconsistent multiplicity (ibid.: 23-30), ordinarily concealed either by the structure of the situation (in the ontological terms of Being and Event) or the transcendental order of the world (in the phenomenological terms of Logics of Worlds).

\section{Equality of Things as They Are}

It is now easy to see that the truth that brings to appearance the being of the situation itself is strictly identical to Agamben's form-of-life exhausted in bare life or a bios that is its own zoe: both figures render form and content indistinct by exposing one as the other: 'it is the content but nothing contains it; it is form but it no longer forms anything, exposing, thereby, itself.' (Agamben 2014: 38). The 'body of truth' manages not to negate the living body of the human animal through its inclusive exclusion only because what is 'excluded' in it (bare life as pure being) is exactly the same as what it is 'included' into (the truth as pure being). The body of truth is quite literally the same as the body of the living animal, but it is not only that. As we have seen, the truth does not produce any new content of the situation but it nonetheless adds to it something that would have remained unpresentable, had the event not occurred. What the truth procedure adds to the facticity of living bodies is the affirmation of their equality (Badiou 2010: 229-259). Yet, it is important to note that this 'new' content of the truth is not extrinsic to the original situation. Badiou's equality is not defined in programmatic terms as a future condition to be attained in a political project (of recognition, protection, redistribution, etc.), but is rather 'immediately prescriptive' since it always already characterizes the being of every world, however unequally it is ordered in its appearance (Badiou 2008: 171).

[The] word 'equality' must be secured in the absence of any economic connotations (equality of objective conditions, of status, of opportunity). Its subjective trenchancy must be restored: equality is something that opens onto a 
strict logic of the Same. Its advantage, then, lies in its abstraction. Equality here is a purely philosophical name. It is unhitched from every programme. [It means] that no lone singularity can have an entitlement that would render it unequal to any other. This can also be said: the essence of a truth is generic, that is, is without any differential trait that would allow it to be placed in a hierarchy on the basis of a predicate. And again: equality signifies that, from the vantage point of politics, what is presented has no need of being interpreted. What presents itself must be received in the nondescript nature and the egalitarian anonymity of its presentation as such. (Ibid.: 174)

This notion of equality is simply a logical consequence of the genericity of the truth itself and not some extraneous principle or value. It arises out of the very character of the truth procedure as the ascent to appearance of the unpresented elements in the form of the indiscernible subset, which does not possess any 'differential trait' that would allow any unequal relation to be constituted. Badiou's equality is never economic, legal, cultural or any other specific equality, but the equality of beings in their being, whatever these beings are in their worldly appearance, identity or role. Equality is not a positive principle defining a certain bios, yet neither is it immediately given in the simple fact of zoe: were it not for the event, the unpresented elements of the situation would have remained such and the worldly hierarchies would have been maintained. Equality as truth is rather the result of the raising of the ontological attributes of zoe to the status of bios, the affirmation of unqualified and indeterminate life as the sole content of politics.

While Agamben hardly ever uses the concept of equality, due to the above-discussed wariness of relying on the key terms of the Western tradition, axiomatic or immediately prescriptive equality follows logically from his concepts of whatever being and being-thus: beings subtracted from every possible qualification, determination or predicate cannot but be equal. The same applies to the notion of communism: while Badiou has enthusiastically reaffirmed the idea of communism in the post-Cold War context, unhesitantly dehistoricising it as an eternal truth or at least a 'hypothesis', Agamben has been rather reticent about it, addressing the idea of communism only rarely and in a somewhat esoteric manner, e.g. in the context of the discussion of pornography or monastic life (1995: 73-74; 2013: 10). There are evident advantages and drawbacks to both strategies. Rather than try to adjudicate between the two we must recognize that despite their different terminological choices Agamben and Badiou have developed two versions of the same political logic that constitutes a positive form of life out of the condition proper to the 
unqualified being of any being whatsoever. The opposition between the 'secret persistence of bare life' and the 'affirmative becoming of truths' is therefore undone or at least relocated to the more superficial level of aesthetic preference. It is out of bare life that truths become and throughout their becoming, be it faint or bombastic, they remain the truths of bare life, which alone warrants an affirmation of equality that is not positive, programmatic or normative, but rather ontological.

In 2002 Agamben ended his lecture on the concept of the paradigm at the European Graduate School on a quote from Wallace Stevens, just like Badiou had done a few days earlier: 'Following Badiou's example, I propose to inaugurate a tradition here in Saas-Fee: every lecture must end with a quotation from Wallace Stevens.' (Agamben 2002) As Simon Critchley has demonstrated in his book on Stevens, the latter was the paradigmatic poet of the 'sheer 'there is' of things' (2005: 86) that are indifferent to human attempts to grasp them and make them meaningful. Agamben and Badiou are certainly not alone among contemporary philosophers in affirming this persistent facticity of being, but they have arguably gone farthest in making this facticity a counter-intuitive source of radical political affirmation, whereby the being of things 'as they are' authorizes the overcoming the present order of things. It would therefore be appropriate to conclude by suggesting that both Agamben and Badiou respond, in their own ways, to the demand of the audience to Stevens's 'man with the blue guitar' to '[play] a tune beyond us, yet ourselves, a tune upon the blue guitar of things exactly as they are' (Stevens 1990: 164).

\section{BIBLIOGRAPHY}

Agamben, G. (1993), The Coming Community, Minneapolis: University of Minnesota Press. Agamben, G. (1995), The Idea of Prose, New York: SUNY Press.

Agamben, G. (1998), Homo Sacer: Sovereign Power and Bare Life, Stanford: Stanford University Press. Agamben, G. (1999), Potentialities: Selected Essays in Philosophy, Stanford: Stanford University Press. Agamben, G. (2000), Means without End: Notes on Politics, Minneapolis: University of Minnesota Press.

Agamben, G. (2002), 'What is a Paradigm?' Lecture at the European Graduate School: http://www.egs.edu/faculty/giorgio-agamben/articles/what-is-a-paradigm/. 
Agamben, G. (2005), The Time that Remains: A Commentary on the Letter to the Romans, Stanford: Stanford University Press.

Agamben, G. (2007a), Infancy and History: On the Destruction of Experience, London: Verso.

Agamben, G. (2007b), Profanations, New York: Zone Books.

Agamben, G. (2010), Nudities, Stanford: Stanford University Press.

Agamben, G. (2011), The Kingdom and the Glory: For a Theological Genealogy of Economy and Government, Stanford: Stanford University Press.

Agamben, G. (2013), The Highest Poverty: Monastic Rules and Form-of-Life, Stanford: Stanford University Press.

Agamben, G. (2014), The Unspeakable Girl, New York: Seagull.

Badiou, A. (2001a), Ethics: An Essay on the Understanding of Evil, London: Verso.

Badiou, A. (2001b), Saint Paul: The Foundation of Universalism, Stanford: Stanford University Press.

Badiou, A. (2005a), Being and Event, London: Continuum.

Badiou, A. (2005b), 'Universal Truths and the Question of Religion', Journal of Philosophy and Scripture, 3: 1, 38-42.

Badiou, A. (2007), The Century, London: Polity.

Badiou, A. (2008), Conditions, London: Continuum.

Badiou, A. (2009), Logics of Worlds, London: Continuum.

Badiou, A. (2010), The Communist Hypothesis, London: Verso.

Baker, G. (2013), 'The Revolution is Dissent: Reconciling Agamben and Badiou on Paul', Political Theory 41(2): 312-335.

Benjamin, W. (1978), Reflections, New York: Schocken Books.

Benjamin, W. (1969), Illuminations, New York: Schochen Books.

Bernstein, J.M. (2004), 'Bare Life, Bearing Witness: Auschwitz and the Pornography of Horror', Parallax, 10: 1, 2-16.

Chiesa, L. (2009), 'Giorgio Agamben's Franciscan Ontology', Cosmos and History, 5: 1, available at http://cosmosandhistory.org/index.php/journal/article/view/130/239, last accessed 20 April 2013.

Clemens, J. (2008), 'The Role of the Shifter and the Problem of Reference in Giorgio Agamben' in J. Clemens, N. Heron and A. Murray (eds), The Work of Giorgio Agamben: Law, Literature, Life, Edinburgh: Edinburgh University Press.

Critchley, S. (2005), Things Merely Are: Philosophy in the Poetry of Wallace Stevens, London: Routledge. Esposito, R. (2008), Bios: Biopolitics and Philosophy, Minneapolis: University of Minnesota Press. Hallward, P. (2003), Badiou: A Subject to Truth, Minneapolis: The University of Minnesota Press. 
Johnston, A. (2013), Prolegomena to any Future Materialism, Volume One: The Outcome of Contemporary French Philosophy, Chicago: Northwestern University Press.

Kaufman, E. (2008), 'The Saturday of Messianic Time: Agamben and Badiou on the Apostle Paul', South Atlantic Quarterly 107 (1):37-54.

Lewis, T. (2007), 'Philosophy - Aesthetics - Education: Reflections on Dance', The Journal of Aesthetic Education 41(4): 53-66.

Livingston, P. (2009), 'Agamben, Badiou and Russell', Continental Philosophy Review 42: 297-325.

Prozorov, S. (2011), 'Pornography and Profanation in the Political Philosophy of Giorgio Agamben', Theory, Culture and Society, 28: 4, 71-95.

Prozorov, S. (2013), 'Living Ideas and Dead Bodies: The Biopolitics of Stalinism', Alternatives 38 (3): 208-227.

Stevens, W. (1990), The Collected Poems of Wallace Stevens, New York: Vintage.

Whyte, J. (2009), 'I Would Prefer Not To: Giorgio Agamben, Bartleby and the Potentiality of the Law', Law and Critique 20, 309-324.

Wolfe, C. (2013), Before the Law: Humans and Other Animals in a Biopolitical Frame, Chicago: The University of Chicago Press.

Zizek, S. (2006), The Parallax View, Cambridge: The MIT Press. 